\title{
DESAIN MODEL PRAKARYA DAN KEWIRAUSAHAAN BERBASIS EKONOMI KREATIF BERDIMENSI INDUSTRI KEUNGGULAN LOKAL
}

\author{
Sukardi \\ Fakultas Keguruan dan Ilmu Pendidikan Universitas Mataram \\ e-mail: kardi_unram@yahoo.co.id
}

\begin{abstract}
Abstrak: Penelitian bertujuan untuk menghasilkan model pendidikan prakarya dan kewirausahaan berbasis ekonomi kreatif berdimensi industri keunggulan lokal yang efektif bagi lulusan SMA berjiwa wirausaha. Penelitian menggunakan prosedur research and development yang dipadukan dengan prinsip desain konstruktivistik dengan tahapan: studi pendahuluan, pengembangan produk awal, dan uji produk awal melalui uji validasi ahli dan praktisi; uji terbatas secara bersiklus, uji produk akhir melalui quasi eksperimen, dan desiminasi serta implementasi. Hasil penelitian tahap pertama adalah sebagai berikut. Industri kerajinan lokal dan pemasarannya menjadi prioritas substansi prakarya dan kewirausahaan dengan menggunakan pembelajaran konstruktivisme social. Desain model terdiri atas tiga komponen, yaitu tujuan (tujuan mata pelajaran, kompetensi dasar, dan indikator), prosedur pembelajaran (pengorganisasian dan penyampaian materi serta pengelolaan pembelajaran), dan penilaian. Desain model menghasilkan produk yang berupa: rumusan kompetensi dasar, silabus, buku ajar, panduan pembelajaran, media, rencana pelaksanaan pembelajaran, dan perangkat penilaian. Hasil uji produk awal menunjukkan bahwa secara keseluruhan rancangan model dan produk yang dihasilkan pada kategori sangat baik.
\end{abstract}

Kata Kunci: desain model, prakarya dan kewirausahaan, ekonomi kreatif

\section{MODEL DESIGN OF PRAKARYA AND ENTREPRENEURSHIP WITH CREATIVE ECONOMY BASED AND LOCAL QUALITY OF INDUSTRY DIMENSION}

\begin{abstract}
This study aims to produce education model of prakarya and entrepreneurship with creative economy based and local quality of industry dimension to the graduated students of Senior High School who have entrepreneur passion. This study used research and development procedure with constructivism design which included the introduction study, initial product development, and initial product test through expert and practitioner validity; limited test in cycle, final product test through quasi experiment, dissemination, and implementation. The first result of the study is as follow. Local handicraft industry and its marketing became the substantial priority of prakarya and entrepreneurship by using social constructivism learning. The model design consists of three components, such as objective (learning objective, basic competency, and indicator), learning procedure (material organization, material delivery and learning management), and evaluation. Model design produce a product which include basic competency formula, syllabus, handout, learning guide, media, lesson plan, and evaluation. The result of the initial product showed that all of produced model plan and product is categorized into good.
\end{abstract}

Keywords: model design, prakarya and entrepreneurship, creative economy

\section{PENDAHULUAN}

Sebagian besar ahli kewirausahaan sepakat bahwa kompetensi wirausaha berupa kemampuan berpikir kreatif dan bertindak inovatif menjadi muara utama pendidikan kewirausahaan (Wennekers \& Thurik, 1999; Zimmerer dkk., 2008:4). Muara ini juga sejalan dengan gelombang perada- ban ekonomi kreatif yang menempatkan kreativitas manusia sebagai faktor produksi utama dalam kegiatan ekonomi (Howkins, 2001; Florida, 2002; Rautkorpi, 2007; Pang, 2009; Macdonald, 2013). Howkins (2001) misalnya menyebutkan ekonomi kreatif sebagai "an economy in which ideas, not land or capital, are the most important factors 
of production". Kedua teori ini sangat relevan dengan tuntutan Kurikulum 2013, khususnya pada mata pelajaran Prakarya dan Kewirausahaan Sekolah Menengah Atas (SMA) yang menekankan pada tercapainya lulusan yang produktif, kreatif, dan inovatif(Kemdikbud, 2013). Prakarya dan Kewirausahaan sendiri merupakan mata pelajaran yang "mengembangkan pengetahuan dan melatih keterampilan kecakapan hidup berbasis seni, teknologi, dan ekonomi” (Kemdikbud, 2014). Lebih lanjut disebutkan bahwa salah satu tujuan mata pelajaran ini adalah "menumbuhkembangkan jiwa wirausaha melalui melatih dan mengelola penciptaan karya (produksi), mengemas, dan usaha menjual berdasarkan prinsip ekonomis, ekosistemik dan ergonomis" (Kemdikbud, 2014).

Namun demikian, permasalahan yang terkuak berdasarkan hasil-hasil penelitian terdahulu dan menjadi fokus penelitian ini adalah sebagai berikut. Pertama, kecenderungan lulusan SMA yang kurang mampu menciptakan lapangan kerja (Wildan dkk, 2011) terindikasi pada 9.74\% lulusan SMA menjadi pengangguran, belum termasuk setengah menganggur (BPS, 2013a). Fakta lain yang terkait adalah hanya sekitar 25\% yang melanjutkan studi ke Perguruan Tinggi (Dinas Dikpora NTB, 2012), terindikasi pada pencapaian Angka Partisipasi Kasar Perguruan Tinggi (APK PT) yang baru menyentuh angka 18,53\% (BPS, 2013b). Kedua, pendidikan kewirausahaan yang dikembangkan cenderung teoritis dan tidak bersentuhan/relevan dengan permasalahan sosial tersebut (Sukardi dkk, 2012), tidak terkait dengan kebutuhan dan potensi industri keunggulan lokal sekitar siswa, padahal potensi tersebut sangat memadai (Sukardi dkk, 2012; Wildan dkk, 2011; Sulaimi dkk, 2010). Keunggulan lokal sendiri merupakan "segala hal yang menjadi ciri khas kedaerahan pada semua aspek" (Supeno, 2007) yang menurut Dediwitagama (Direktorat Pembinaan SMA, 2007c) berbentuk "hasil bumi, kreasi seni, tradisi, budaya, pelayanan, jasa, sumber daya alam, sumber daya manusia atau lainnya yang menjadi keunggulan suatu daerah".

Ketiga, peluang pembentukan kemampuan berpikir kreatif dan bertindak inovatif melalui pendidikan Prakarya dan Kewirausahaan juga belum sesuai dengan harapan Kurikulum 2013
(Sukardi, 2014), karena guru belum memiliki acuan dalam membelajarkan mata pelajaran tersebut. Keempat, penelahaan terhadap hasil-hasil penelitian tentang pendidikan kewirausahaan juga menunjukkan temuan yang kurang konsisten. Di satu sisi berdampak positif terhadap sikap kewirausahaan (Packham dkk., 2010; Sowmya $\mathrm{dkk}, 2010$ ), namun disisi lain belum mampu membentuk kompetensi wirausaha (Cheng dkk, 2009). Ketidakkonsistenan hasil-hasil tersebut disinyalir karena adanya perbedaan konten, strategi, media, dan lainnya.

Kelima, terhadap permasalahan tersebut, maka diperlukan konstruksi pendidikan kewirausahaan sesuai dengan konteks ke Indonesiaan. Dalam konteks tersebut, maka pemikiran teori rekonstruksi sosial sangat relevan, karena menempatkan pendidikan yang terintegrasi dengan lingkungan, pemecahan permasalahan sosial, serta substansinya digali dari potensi sekitar siswa. Teori ini juga menempatkan realitas sebagai konstruksi sosial yang diciptakan oleh individu terhadap dunia sosial di sekelilingnya. Dalam konteks pembelajaran, teori ini menempatkan proses pembelajaran sebagai proses bersama, interaksi, dan kerjasama (McNeil, 2006:36). Hasil kajian terdahulu menemukan bahwa pembelajaran kewirausahaan yang menekankan pada interaksi sosial berhubungan positif dengan keinginan berwirausaha siswa (Man \& Yu, 2007; Jha, 2012).

Berdasarkan temuan-temuan dan sandaran teoritis tersebut, kajian ini menjadi penting untuk menggagas inovasi pengembangan Prakarya dan Kewirausahaan berbasis ekonomi kreatif berdimensi industri keunggulan lokal dengan bersandarkan pada teori rekonstruksi sosial sebagai upaya membentuk lulusan berjiwa wirusaha, khususnya kemampuan berfikir kreatif dan bertindak inovatif dalam menciptakan produk/jasa. Inovasi ini juga dilakukan untuk mempertegas status penelitian sebelumnya (Sukardi dkk, 2014) melalui konstruksi pendidikan kewirausahaan dalam konteks ke Indonesiaan. Oleh karenanya, tujuan penelitian tahap pertama ini, yaitu: (1) memperoleh design model pendidikan Prakarya dan Kewirausahaan berbasis ekonomi kreatif berdimensi industri keunggulan lokal jenjang SMA. Komponennya diadaptasi dari variabel pembelajaran menurut Reigeluth dan Meriill 
(1978:1979), meliputi aspek tujuan, prosedur pembelajaran, dan penilaian; (2) memperoleh prototipe produk model pendidikan, berupa rumusan/ penajaman kompetensi dasar (KD), silabus, buku ajar, buku panduan pembelajaran, media, rencana pelaksanaan pembelajaran (RPP), dan perangkat penilaian.

\section{METODE}

Penelitian ini menggunakan model penelitian dan pengembangan (research and development) yang mengacu pada Borg dan Gall (1983). Dalam pelaksanaannya, langkah-langkah model ini dimodifikasi dan dikombinasikan dengan prinsip-prinsip design berorientasi konstruktivistik (Willis, 2000). Paling tidak ada beberapa tahapan utama dalam kajian ini, yaitu: (a) tahap awal, berupa studi pendahuluan, pengembangan produk awal, uji produk awal melalui uji ahli dan praktisi; dan (b) tahap kedua, berupa uji produk awal melalui uji terbatas, uji lapangan melalui uji quasi eksperimen, desiminasi dan implementasi (divisualisasikan dalam Gambar 1).

Studi pendahuluan dilakukan menggunakan metode fishbone diagram sebagaimana disarankan Kaoru Ishikawa (Tambupolon, 2001:115) yang meliputi aspek orang, bahan, prosedur, peralatan, dan lingkungan. Subjek yang diwawancarai adalah guru Prakarya dan Kewirausahaan, kepala sekolah, wakil bidang kurikulum yang ditentukan secara cluster sampling. Dari lima Kabupaten/ Kota di Pulau Lombok, ditetapkan Kota Mataram mewakili industri kerajinan perhiasan emas/perak/ mutiara dan Kabupaten Lombok Barat mewakili industri kerajinan kain batik khas lokal. Selain itu, juga diwawancarai komite sekolah, dewan pendidikan, tim pengembang kurikulum Dinas Pendidikan setempat, dan kelompok pengusaha keterampilan/kerajinan lokal atau dunia usaha (DU)/dunia kerja (DK) sebagai informan yang ditentukan secara purposive sampling. Pengumpulan data menggunakan kuesioner, panduan Focus Group Discussion (FGD), wawancara, dan kajian dokumen. Instrumennya berupa kuesioner yang disusun dalam bentuk semantic differential, panduan FGD, panduan wawancara untuk memperoleh data atau fakta tentang permasalahan, kebutuhan, dan daya dukung sekolah terkait Prakarya dan Kewirausahaan. Kajian dokumen dilakukan untuk melengkapi dan verifikasi hasil khususnya terkait kebijakan pengembangan Prakarya dan Kewirausahaan, dokumen kompetensi inti dan $\mathrm{KD}$, silabus, buku ajar, dan perangkat pendukung lainnya yang dimiliki sekolah.

Tahap pengembangan produk awal dilakukan dalam bentuk penyusunan design model dan penyusunan prototipe produk model. Penyusunan design ini dilakukan menggunakan design terbalik sebagaimana disarankan oleh Gagne dkk (1992:235), yaitu dengan menetapkan hasil belajar terlebih dahulu. Hasil penyusunan design menjadi dasar menyusun prototipe produk, berupa penajaman KD, silabus, buku ajar, buku panduan pembelajaran, media, RPP, dan perangkat penilaian. Subjek yang dilibatkan juga sama dengan subjek sebagaimana studi pendahuluan. Kelayakan hasil pengembangan diukur dari ketepatan design dengan hasil belajar yang dirumuskan, sedangkan kelayakan prototipe produk diukur dari ketepatan dengan design yang dihasilkan. Untuk itu, instrumen yang digunakan adalah panduan FGD dan panduan wawancara kelayakan hasil pengembangan.

Uji produk awal dilakukan dengan dua cara, yaitu melalui uji validasi ahli/praktisi dan uji coba terbatas. Untuk tahap awal hanya dilakukan uji validasi dengan melibatkan 1 orang ahli teknologi pembelajaran (TP), 1 orang ahli Bahasa Indonesia (BI), dan melibatkan praktisi (DU/DK/pengrajin setempat). Instrumen untuk uji validasi menggunakan kuesioner yang diadaptasi dari indikator yang dikembangkan oleh Direktorat Pembinaan SMA (2007a; 2007b). Instrumen uji validasi oleh praktisi dijaring menggunakan panduan FGD. Penilaian dan masukan pada tahap uji produk awal dijadikan dasar melakukan perbaikan produk. Data hasil validasi ahli dan praktisi dianalisis menggunakan teknik deskriptif kuantitatif. Skor berada dalam interval 1-5, sehingga kriteria interpretasinya, yaitu: sangat baik, jika rata-rata penilaian atau tanggapan $(p t)>4$; baik, jika $3<p t$ d" 4; cukup, jika $2<p t$ d" 3 ; kurang, jika $1<p t$ d" 2 ; sangat kurang $p t=1$. 


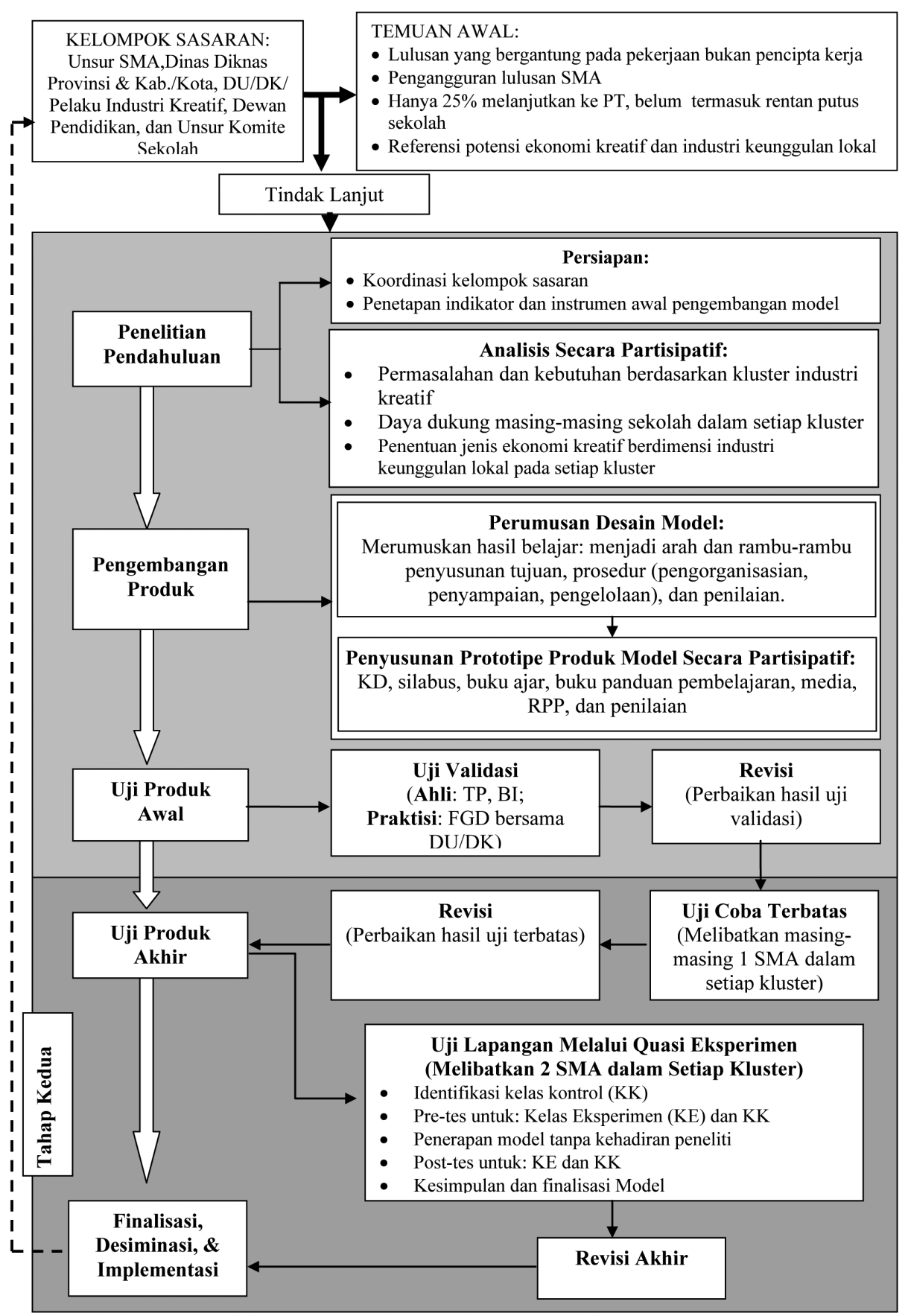

Gambar 1. Alur Penelitian dan Pengembangan

\section{HASIL DAN PEMBAHASAN Hasil}

Paparan hasil ini meliputi paparan tentang deskripsi hasil studi pendahuluan, model yang dikembangkan, dan hasil uji coba produk awal (uji ahli dan praktisi).

\section{Deskripsi Hasil Studi Pendahuluan}

Permasalahan Prakarya dan Kewirausahaan berdasarkan fishbone diagramnya Ishikawa (Tambupolon, 2001:115) menunjukkan temuan sebagai berikut. Pertama, dari aspek bahan ditemukan bahwa konten pembelajaran belum mengarah pada pembentukan berfikir kreatif dan bertindak inovatif, hanya berupa kumpulan buku teks kewirausahaan secara umum, dan belum berbasis ekonomi kreatif berdimensi pemanfaatan industri keunggulan lokal. Kedua, aspek proses pembelajaran cenderung ceramah, minimnya kegiatan bersama dan interaksi, serta tanpa melalui praktik kewirausahaan secara langsung. Ketiga, aspek orang menunjukan ketersediaan guru Prakarya 
dan Kewirausahaan memadai, meskipun kelemahannya adalah kemampuan dalam memperluas dan memperdalam isi dan proses pembelajaran Prakarya dan Kewirausahaan. Keempat, aspek peralatan sudah tersedia meskipun belum memadai. Kelima, aspek lingkungan menunjukkan bahwa dukungan yang kuat dari pengrajin/dunia usaha dalam menfasilitasi praktik kewirausahaan siswa.

Hasil analisis kebutuhan bersama subjek menemukan bahwa pembelajaran Prakarya dan Kewirausahaan berbasis ekonomi kreatif berdimensi keunggulan lokal sangat diharapkan, apalagi potensi tersebut tersedia di sekitar sekolah. Hasil penulusuran terhadap kebutuhan siswa dan subjek penelitian menempatkan keterampilan produksi industri keunggulan lokal, seperti kerajinan khas lokal sebagai prioritas utama. Hasil analisis ini sejalan dengan tujuan mata pelajaran Prakarya dan Kewirausahaan sebagai salah satu bentuk muatan lokal. Salah satu tujuan mata pelajaran ini adalah "untuk membekali siswa dengan keterampilan melalui pemanfaatan potensi keunggulan lokal" (Direktorat Pembinaan SMA, 2007b). Mengacu pada tujuan ini, maka Pakarya dan Kewirausahaan ditekankan pada pembentukan kompetensi wirausaha, sehingga tujuan ini cenderung mengarahkan pada tujuan orientatif prosedural dan pendukung prasyarat tentang langkah-langkah prosedur dalam melaksanakan kegiatan produksi secara urut sebagaimana yang disarankan Degeng (2013).

\section{Deskripsi Hasil Pengembangan}

Sebagaimana disebutkan pada bagian metode bahwa pengembangan model menggunakan design terbalik sebagaimana saran Gagne dkk (1992), berupa perumusan hasil belajar terlebih dahulu. Dengan demikian, mengacu pada hasil analisis permasalahan dan kebutuhan, maka rumusan hasil belajarnya adalah siswa memiliki kompetensi kreatifitas dan inovatif dalam memproduksi kerajinan industri keunggulan lokal. Rumusan hasil belajar tersebut menjadi

Tabel 1. Design Model Prakarya dan Kewirausahaan Berbasis Ekonomi Kreatif Berdimensi Industri Keunggulan Lokal

\begin{tabular}{|c|c|c|}
\hline No. & $\begin{array}{l}\text { Komponen } \\
\text { Model }\end{array}$ & Penjelasan \\
\hline 1 & $\begin{array}{l}\text { Tujuan } \\
\text { Pembelajaran }\end{array}$ & $\begin{array}{l}\text { Memuat tujuan mata pelajaran, kompetensi inti, kompetensi dasar, dan } \\
\text { indikator. Keseluruhan tujuan ditekankan pada kemampuan produksi } \\
\text { kerajinan industri keunggulan lokal termasuk pemasarannya. } \\
\text { Konstruksinya mengarah pada tujuan orientatif prosedural, formulasi } \\
\text { dalam bentuk yang operasional, dan berbentuk produk belajar. }\end{array}$ \\
\hline \multirow[t]{4}{*}{2.} & \multicolumn{2}{|c|}{ Prosedur Pembelajaran } \\
\hline & $\begin{array}{l}\text { a. Pengorgani- } \\
\text { sasian Materi }\end{array}$ & $\begin{array}{l}\text { Mencakup penataan materi, penyajian kompetensi dasar dan indikator, } \\
\text { desain teks dan gambar, rangkuman, evaluasi, tugas/latihan, daftar } \\
\text { pustaka, dan glossary. Pengurutan materi tetap menggunakan pendekatan } \\
\text { prosedural prasyarat yang menunjukkan urutan-urutan dalam } \\
\text { menampilkan langkah-langkah prosedur produksi. }\end{array}$ \\
\hline & $\begin{array}{l}\text { b.Penyampaian } \\
\text { Materi }\end{array}$ & $\begin{array}{l}\text { Penyampaian materi menggunakan pendekatan rekonstruksi sosial yang } \\
\text { menekankan pada kerjasama, interaksi, komunikasi, dan praktik } \\
\text { langsung. Implementasinya diwujudkan dalam bentuk: (a) pembelajaran } \\
\text { dalam kelompok belajar; (b) tatap muka; dan (c) penugasan terstruktur } \\
\text { di luar kelas melalui praktik bersama pengrajin atau dunia usaha. }\end{array}$ \\
\hline & $\begin{array}{l}\text { c. Pengelolaan } \\
\text { Pembelajaran }\end{array}$ & $\begin{array}{l}\text { Tahapan pembelajaran mengikuti sintaks rekonstruksi sosial, yaitu: (a) } \\
\text { pengaktifan pengetahuan awal; (b) penyajian pengetahuan baru; (c) } \\
\text { latihan pemahaman; (d) praktik di luar jam pelajaran (out class) bersama } \\
\text { pengrajin/DU/DK; dan (e) refleksi terhadap proses dan hasil latihan. }\end{array}$ \\
\hline 3. & Penilaian & $\begin{array}{l}\text { Penilaian diarahkan pada penggunaan penilaian berbasis proyek, } \\
\text { mencakup: (a) pedoman tugas proyek secara berkelompok; (b) kriteria } \\
\text { penilaian pada setiap aspek (perencanaan, pelaksanaan, hasil/produk, dan } \\
\text { pelaporan); (c) instrumen; dan (d) rubrik penilaian. }\end{array}$ \\
\hline
\end{tabular}


dasar mengembangkan rancangan model yang terdiri dari tiga komponen utama, yaitu: tujuan, prosedur pembelajaran, dan penilaian. Ketiga aspek ini menjadi komponen utama model yang dimodifikasi dari variabel pembelajaran menurut Reigeluth dan Merrill (1978:1979), berupa kondisi pembelajaran, metode pembelajaran, dan hasil pembelajaran. Secara khusus, untuk prosedur pembelajaran diadopsi dari pendapat Reigeluth dan Merrill (1978) yang membaginya menjadi tiga komponen, yaitu pengorganisasian materi, penyampaian materi, dan pengelolaan pembelajaran. Design model Prakarya dan Kewirausahaan berbasis ekonomi kreatif berdimensi industri keunggulan lokal disajikan dalam Tabel 1. Model yang dihasilkan dilengkapi dengan prototipe produknya, meliputi: rumusan $\mathrm{KD}$, silabus, buku ajar, buku panduan pembelajaran, media, RPP, dan perangkat penilaian.

Berdasarkan rancangan yang dihasilkan pada Tabel 1 di atas kemudian disusun produknya berupa penajaman $\mathrm{KD}$, silabus, buku ajar, media, buku panduan pembelajaran, RPP, dan perangkat penilaian. KD dan silabus disusun berdasarkan hasil penyusunan rancangan model dengan menempatkan ketrampilan produksi kerajinan sebagai fokus utama di samping pemasaran. Buku ajar sebagai produk model juga disusun berdasarkan hasil rancangan (design) model yang disusun dengan alur: menentukan identitas buku ajar, analisis instruksional, identifikasi subordinate skill (indikator), deskripsi materi buku ajar berdasarkan subordinate skill, dan menentukan evaluasi dalam buku ajar.
Penyusunan panduan pembelajaran diadaptasi dari panduan yang dikembangkan oleh Puskur Balitbang (2006). Komponennya, yaitu tujuan, pertanyaan kunci, petunjuk umum bagi guru, bahan dan alat, alokasi waktu, rangkuman langkah-langkah pembelajaran, deskripsi langkah-langkah pembelajaran, dan rambu-rambu evaluasi pembelajaran. Media pembelajaran dikemas menggunakan multimedia interaktif dengan memanfaatkan macromedia flash, yang di dalamnya terdapat teks, gambar, suara, dan video sesuai tuntutan materi. Khusus untuk RPP disusun berdasarkan alur dan struktur penyusunan seperti RPP pada mata pelajaran lain. Produk terakhir adalah penyusunan perangkat penilaian berbasis penilaian proyek sebagaiman tuntutan hasil rancangan model tersebut.

\section{Hasil Uji Produk Awal}

Uji produk awal dilakukan melalui uji ahli dan praktisi. Uji ahli pertama dilakukan untuk menilai kelayakan dan penyajian dengan melibatkan ahli teknologi pembelajaran (Tabel 2). Data Tabel 2 menunjukkan bahwa produk model yang dihasilkan sudah sangat baik dan sudah layak digunakan.

Uji selanjutnya adalah sisi kebenaran substansinya yang dilakukan melalui FGD bersama pengrajin/DU/DK (hasil pengujian pada Tabel 3). Secara keseluruhan menunjukkan bahwa isi substansi Prakarya dan Kewirausahaan sudah sesuai dengan ekonomi kreatif berdimensi keunggulan lokal. Di samping itu, tahapan produksinya

Tabel 2. Hasil Uji Kelayakan dan Penyajian Produk Model Prakarya Kewirausahaan Berbasis Ekonomi Kreatif Berdimensi Industri Keunggulan Lokal

\begin{tabular}{|c|c|c|c|}
\hline & Produk Model & Rata $^{2}$ Penilaian* & Kategori Penilaian** \\
\hline 1. & Rumusan KD & 4.2 & Sangat Baik \\
\hline 2. & Buku Ajar untuk Siswa & 3.7 & Baik \\
\hline 3. & Silabus & 4.1 & Sangat Baik \\
\hline 4. & Panduan Pembelajaran untuk Guru & 4.5 & Sangat Baik \\
\hline 5. & Rencana Pelaksanaan Pembelajaran (RPP) & 4.3 & Sangat Baik \\
\hline 6. & Media & 3.8 & Baik \\
\hline 7. & Perangkat Penilaian Berbasis Proyek & 4.1 & Sangat baik \\
\hline \multicolumn{2}{|c|}{ Keseluruhan } & 4.1 & Sangat Baik \\
\hline \multicolumn{4}{|c|}{$\begin{array}{l}\text { * Skor penilaian berada pada interval } 1-5 \\
\text { **Kriteria: } p t>4 \text { (Sangat baik); } 3<p t \leq 4 \text { (Baik); } 2<p t \leq 3 \text { (Cukup); } 1<p t \leq 2 \text { (Kurang); dan } p t \\
\quad=1 \text { (Sangat kurang), dimana } p t \text { adalah penilaian atau tanggapan ahli teknologi pembelajaran }\end{array}$} \\
\hline
\end{tabular}

Desain Model Prakarya dan Kewirausahaan Berbasis Ekonomi Kreatif Berdimensi Industri Keunggulan Lokal 
Tabel 3. Hasil Uji Kebenaran Isi Substansi Prakarya dan Kewirausaahaan Berbasis Ekonomi Kreatif Berdimensi Industri Keunggulan Lokal

\begin{tabular}{clcc}
\hline No. & Aspek Penilaian & Skor * & Kategori Penilaian** \\
\hline 1. & Kebenaran KD & 5 & Sangat Baik \\
\hline 2. & Kebenaran indikator & 4 & Baik \\
\hline 3. & Cakupan materi & 5 & Sangat Baik \\
\hline 4. & Kedalaman materi & 5 & Sangat Baik \\
\hline 5. & Urutan materi & 5 & Sangat Baik \\
\hline 6. & Ketepatan gambar & 5 & Sangat Baik \\
\hline 7. & Kebermanfaatan materi & 4 & Baik \\
\hline Keseluruhan & 4.71 & Sangat Baik \\
\hline * Skor penilaian berada pada interval $1-5$ & & \\
** Kriteria: $p t>4$ (Sangat baik); $3<p t \leq 4$ (Baik); $<p t \leq 3$ (Cukup); $1<p t \leq 2$ (Kurang); dan \\
$p t=1$ (Sangat kurang), dimana $p t$ adalah penilaian atau tanggapan praktisi/pengrajin/DU/DK
\end{tabular}

Tabel 4. Hasil Uji Ketepatan Bahasa Produk Model Prakarya dan Kewirausahaan Berbasis Ekonomi Kreatif Berdimensi Industri Keunggulan Lokal

\begin{tabular}{clcc}
\hline No. & Aspek Penilaian & Skor $*$ & Kategori Penilaian** \\
\hline 1. & Kemudahan dibaca & 4 & Baik \\
\hline 2. & Kejelasan isi atau informasi & 5 & Sangat Baik \\
\hline 3. & Susunan kalimat & 4 & Baik \\
\hline 4. & Kebenaran penggunaan bahasa & 4 & Baik \\
\hline 5. & Kesederhanaan bahasa & 4 & Baik \\
\hline 6. & Penggunaan tanda baca & 4 & Baik \\
\hline 7. & Hubungan antar kalimat & 5 & Sangat Baik \\
\hline 8. & Ukuran dan jenis huruf & 5 & Sangat Baik \\
\hline 9. & Jarak dan spasi & 5 & Sangat baik \\
\hline 10. & Penggunaan ilustrasi/gambar & 4 & Baik \\
\hline Keseluruhan & 4.4 & Sangat Baik \\
\hline$*$ Skor penilaian berada pada interval 1-5 & & \\
$* *$ Kriteria: $p t>4$ (Sangat baik); $3<p t \leq 4$ (Baik); $2<p t \leq 3$ (Cukup); $1<p t \leq 2$ (Kurang); dan \\
$p t=1$ (Sangat kurang), dimana $p t$ adalah penilaian atau tanggapan ahli Bahasa Indonesia \\
\hline Sumber: Pengolahan Data Primer
\end{tabular}

sebagaimana termuat dalam rumusan KD dan indikator sudah benar.

Uji ahli terakhir adalah dari sisi ketepatan penggunaan bahasa Indonesia. Hasil uji menunjukkan bahwa seluruh produk model (khususnya buku ajar dan buku panduan pembelajaran) sudah memenuhi kaidah penggunaan bahasa Indonesia yang benar. Beberapa masukan yang sudah direvisi adalah terkait penggunaan tata bahasa dan perampingan gambar/ilustrasi.

\section{Pembahasan}

Temuan awal sebagaimana dipaparkan di atas telah meneguhkan hasil-hasil kajian sebelumnya (Sukardi dkk, 2014) bahwa pendidikan kewirausahaan yang bersandarkan pada rekonstruksi sosial relevan dengan pemecahan permasalahan sosial. Penempatan penyelesaian permasalahan sosial menjadi muara teori ini (Stanley, 1981) sehingga berimplikasi pada beberapa hal berikut. Pertama, bahwa konten/materi yang digunakan bersumber dari potensi sekitar peserta didik sebagaimana yang ditegaskan oleh George S. Counts (White, 2002). Ahli psikologi seperti Keller (1983) juga sependapat tentang pentingnya materi yang relevan kebutuhan peserta didik sehingga dapat menarik minat dan motivasi belajar peserta didik. Dalam kajian ini, konten/ materi Prakarya dan Kewirausahaan menempatkan potensi ekonomi kreatif berdimensi industri keunggulan lokal sebagai sumber materinya sehingga dapat berkontribusi terhadap pemecah- 
an permasalahan sosial. Rancangan ini sejalan temuan White (2002) yang merekomendasikan pentingnya pengembangan kurikulum bidang sosial (termasuk ekonomi) berorientasi pada rekonstruksi sosial untuk menjawab perubahan sosial dan tantangan global.

Implikasi kedua adalah proses pembelajarannya. Rancangan pengelolaan pembelajaran akan dilakukan secara interaktif dengan melibatkan siswa secara aktif. Prinsip-prinsip tersebut sejalan dengan pendapat pemikir rekonstruksi sosial lainnya, seperti Vygotsky (Schunk, 2012) yang menekankan pentingnya interaksi antara aspek internal dan eksternal dari pembelajaran serta dengan lingkungan sosial pembelajaran. Hasil kajian Man dan Yu (2007) juga menempatkan interaksi sebagai inti pembelajaran rekonstruksi sosial. Jauh sebelumnya, Joyce dkk (2001) dalam penelitiannya juga menyarankan implementasi pembelajaran berorientasi rekonstruksi sosial yang menekankan pada pembelajaran partisipatif, dialogis, dan interaktif sehingga memungkinkan siswa mencapai kemampuan berfikir yang lebih tinggi. Pola dan kebiasaan pembelajaran tersebut telah menghasilkan regenerasi sosial dan pembaharuan dalam masyarakat di Amerika Serikat. Proses interaksi tersebut dilakukan tidak hanya di setting dalam kelas melainkan di luar kelas. Pembelajaran di luar kelas didasarkan pada konsep bahwa potensi lokal merupakan sumber belajar berbasis lingkungan, sehingga keberadaan lingkungan menjadi sumber daya yang dapat dimanfatkan oleh siswa. Dengan demikian, pembelajaran di luar kelas memberikan peluang kepada siswa untuk memperoleh pengetahuan dan keterampilan melalui pelibatan dalam dunia nyata. Pembelajaran di luar kelas juga dapat menghindari kejenuhan, kebosanan, dan persepsi belajar hanya di dalam kelas.

Implikasi ketiga adalah bahwa rancangan model yang dihasilkan menggunakan penilaian otentik dalam bentuk penilaian proyek. Penilaian ini lebih diarahkan pada penilaian berbasis bukti nyata berupa unjuk kerja dan produk yang dihasilkan siswa. Implementasi kedua penilaian tersebut diwujudkan dalam bentuk penggunaan penilaian berbasis proyek di samping penilaian selama presentasi hasil dan evaluasi diri. Penilaian proyek dapat menilai hasil dan proses serta dapat dilakukan sendiri oleh siswa, teman sejawat, maupun oleh guru (Bergh dkk, 2006; Puskur Balitbang, 2006).

\section{SIMPULAN}

Berdasarkan pemaparan di atas dapat disimpulkan sebagai berikut. (a) Pelaksanaan pembelajaran berdimensi Kewirausahaan di SMA belum optimal, karena kurang memperhatikan kebutuhan siswa dan potensi ekonomi kreatif berdimensi industri keunggulan lokal sebagai substansinya. Hasil analisis kebutuhan menempatkan keterampilan produksi industri keunggulan lokal, seperti kerajinan khas lokal sebagai substansi Prakarya dan Kewirausahaan dengan menggunakan pendekatan pembelajaran berorientasi rekonstruksi sosial. (b) Model yang dikembangkan terdiri atas tiga komponen utama, yaitu tujuan pembelajaran (kompetensi dasar dan indikator), prosedur pembelajaran (pengorganisasian materi, penyampaian materi, dan pengelolaan pembelajaran), dan penilaian. Dari rancangan model, dihasilkan produk berupa rumusan KD, silabus, buku ajar, buku panduan pembelajaran, media, RPP, dan perangkat penilaian. (c) Hasil uji produk awal melalui uji validasi ahli dan praktisi menunjukkan bahwa secara keseluruhan rancangan dan produk model yang dihasilkan pada kategori sangat baik.

Berdasarkan kesimpulan tersebut, maka untuk tahun pertama ini disarankan kepada sekolah (SMA) yang menerapkan Kurikulum 2013 agar dapat mengadopsi atau mengadaptasi model awal ini sampai dilakukan proses pengujian akhir. Bagi pengambil kebijakan dapat menyebarluaskan model ini melalui penggandaan dan menfasilitasi sekolah untuk membuat program Workshop/ Pendidikan dan Latihan atau sejenisnya. Untuk saran pengembangan produk lanjut, khususnya kepada peneliti lain adalah dapat menggunakan model awal ini sebagai dasar mengembangkan dan perluasan model dan atau perluasan fokus aspek kewirausahaannya.

\section{UCAPAN TERIMA KASIH}

Penelitian ini dibiayai dari Skim Hibah Strategis Nasional 2015. Untuk itu, ucapan terima kasih disampaikan kepada Direktorat Riset dan Pengabdian Masyarakat, Direktorat 
Jenderal Penguatan Riset dan Pengembangan, Kementerian Riset, Teknologi dan Pendidikan Tinggi atas bantuan dan dukungannya. Terima kasih pula disampaikan kepada Dewan Redaksi Cakrawala Pendidikan beserta staf atas perkenan dipublikasikannya hasil kajian ini.

\section{DAFTAR PUSTAKA}

Bergh, V.V.D., Mortelmans, D., Spooren, P., Petegem, P.V., Gijbels, D., \& Vanthournout, G. 2006. "New Assessment Modes Within Project-Based Education-The Stakeholderes". Studies in Educational Evaluation, 32, hlm 345-368.

Borg, W.R. \& Gall, M.D. 1983. Educational Research: an Introduction (4th $\mathrm{ed}$.). New York: Longman, Inc.

Badan Pusat Statistik/BPS. 2013a. "Keadaan Ketenagakerjaan Agustus 2013”. (http:// www. bps.go.id/brs_file/naker_06nov13. pdf). Diunduh 30 Desember 2013.

Badan Pusat Statistik/BPS. 2013b. "Indikator Pendidikan 1994-2012”. (http://www.bps. go.id/tab_sub/ view.php?kat=1\&tabel=1). Diakses 21 Januari 2014.

Cheng, M.Y., Chan, W.S. \& Mahmood, A. 2009. "The Effectiveness of Entrepreneurship Education in Malaysia". Education + Training, 51 (7) hml 555-566.

Degeng, I.N.S. 2013. Ilmu Pembelajaran: Klasifikasi Variabel untuk Pengembangan Teori dan Penelitian. Bandung: ARAS MEDIA.

Dinas Pendidikan Pemuda dan Olah Raga/Dikpora NTB. 2012. Buku Saku Pendidikan Propinsi NTB 2011-2012. Mataram: Dinas Dikpora NTB.

Direktorat Pembinaan SMA. 2007a. Panduan Umum Pengembangan Mulok. Jakarta: Direktorat Pembinaan SMA Departemen Pendidikan Nasional.
Direktorat Pembinaan SMA. 2007b. Panduan Umum Pengembangan Bahan Ajar. Jakarta: Direktorat Pembinaan SMA Departemen Pendidikan Nasional.

Direktorat Pembinaan SMA. 2007c. Konsep dan Strategi Pelaksanaan Pendidikan Berbasis Keunggulan Lokal. Jakarta: Direktorat Pembinaan SMA Departemen Pendidikan Nasional.

Florida, R. 2002. The Rise of The Creative Class. New York: Basic.

Gagne, R.M., Briggs, L.J. \& Walter, W.W. 1992. Principles of Instructional Design ( $4^{\text {th }}$ ed.). Fort Worth, TX: HBJ College Publishers.

Howkins, J. 2001. The Creative Economy: How People Make Money from Ideas. New York: Penguin.

Jha, A. K. 2012. "Epistemological and Pedagogical Concerns of Constructionism: Relating to the Educational Practices". Creative Education, 3 (2), hml 171-178.

Joyce, B., Elizabeth, S., \& Judy, F. 2001. "Social Reconstruction through Video Art: a Case Study". Transformations, 12 (1), hml 93105.

Keller, J.M. Motivational Design of Instruction. Dalam Charles M. Reigeluth (Ed). 1983. Instructional-Design Theories and Models: An Overview of their Current Status. Hillsdale, N.J.: Lawrence Erlbaum Associates.

Kementerian Pendidikan dan Kebudayaan/ Kemdikbud. 2013. Peraturan Menteri Pendidikan dan Kebudayaan Nomor 54 Tahun 2013 Tentang Standar Kompetensi Lulusan Pendidikan Dasar dan Menengah. Jakarta: Kemdikbud.

Kementerian Pendidikan dan Kebudayaan/Kemdikbud. 2014. Materi Pelatihan Guru: Implementasi Kurikulum 2013 Tahun 2014 Mata Pelajaran Prakarya dan Kewirausa- 
haan SMA/SMK. Jakarta: Pusat Pengembangan Profesi Pendidik Badan Pengembangan Sumber Daya Manusia Pendidikan dan Kebudayaan dan Penjaminan Mutu Pendidikan Kementerian Pendidikan dan Kebudayaan.

Macdonald, S. 2013. "Beyond the Creative Industries". International Journal of Education Through Art, 9 (3), hml 293-309.

Man, T.W.Y., \& Yu, C.W.M. 2007. "Social Interaction and Adolescent's Learning in Enterprise Education: an Empirical Study". Education + Tarining, 49 (8), hml 620-633.

McNeil, J.D. 2006. Contemporary Curriculum: In Thought and Action. NJ: John Wiley and Sons, Inc.

Packham, G., Jones, P., Miller, C., Pickernell, D. \& Thomas, B. 2010. "Attitudes Towards Entrepreneurship Education: a Comparative Analysis". Education + Training, 52 (8), hml 568-586.

Pang, L. 2009. "The Labor Factor in the Creative Economy”. Social Text 99, 27 (2): 55-76.

Pusat Kurikulum Badan Penelitian dan Pengembangan/Puskur Balitbang. 2006. Model Penilaian Kelas. Jakarta: Puskur Balitbang Departemen Pendidikan Nasional.

Rautkorpi, T. 2007. "Mentoring in the Creative Economy". International Journal of Education Through Art, 3 (3), hml 231-241.

Reigeluth, C.M. \& Merrill, M.D. 1978. "A Knowledge Base for Improving Our Methods of Instructional". Educational Psychologist, 13, hml 57-70.

Reigeluth, C.M. \& Merrill, M.D. 1979. "Classes of Instructional Variables". Educational Technology, 19 (3), hml 5-24.
Schunk, D.H. Teori-teori Pembelajaran: Perspektif Pendidikan. ( $6^{\text {th }}$ ed.). Terjemahan Eva Hamdiah dan Rahmat Fajar. 2012. Yogyakarta: Pustaka Pelajar.

Sowmya, D.V., Majumdar, S. \& Gallant, M. 2010. "Relevance of Education for Potential Entrepreneurs: an International Investigation". Journal of Small Business and Enterprise Development, 17 (4), hml 626-640.

Stanley, W.B. 1981. "Toward a Reconstruction of Social Education". Theory and Research in Social Education, 9 (1), hml 67-89.

Sukardi, Syafruddin, \& Burhanuddin. 2012. "Penelusuran Permasalahan dan Potensi Pendidikan Menengah Umum untuk Mengukur Peluang Pengembangan Pendidikan Kewirausahaan Berbasis Keterampilan Daerah di Kota Mataram NTB”. Jurnal Penelitian Kependidikan, 22 (1), hml 74-89.

Sukardi, Ismail, M., \& Suryanti, N.M. 2014. "Model Pendidikan Kewirausahaan Berbasis Keterampilan Lokal bagi Anak Putus Sekolah pada Masyarakat Marginal". Cakrawala Pendidikan, 33 (3), hlm 402412.

Sulaimi, M., Karta, I.W., \& Sukardi. 2010. "Pemetaan Permasalahan dan Potensi Pengembangan dan Pelaksanaan KTSP Pendidikan Dasar di Kota Mataram”, Jurnal Kependidikan, 40 (1), hlm 1-15.

Supeno. 2007. Model Pendidikan bagi Masyarakat Marginal. Makalah disajikan dalam Lokakarya Pengembangan Model Pendidikan pada Masyarakat Marginal, Sumbawa, 8-9 September.

Tampubolon, D.P. 2001. Perguruan Tinggi Bermutu: Paradigma Baru Manajemen Pendidikan Tinggi Menghadapi Tantangan Abad Ke-21. Jakarta: Gramedia.

Wennekers \& Thurik, R. 1999. "Linking Entrepreneurship and Economic Growth". 
Journal Small Business Economics, 13 (2), $\mathrm{hml}$ 27-55.

White, S.R. 2002. "Reconstructionism and Interdisciplinary Global Education: Curricula Construction in a Teilhardian Context". International Education Journal, 31 (1), hml 5-23.

Wildan, Sukardi, \& Musaddat, S. 2011. "Naskah Kajian Strategi Perencanaan Pendidikan Menengah di NTB”. Jakarta: Direktorat Jenderal Pendidikan Menengah Kementerian Pendidikan Nasional.
Willis, J. 2000. "The Maturing of Constructivist Instructional Design: Some Basic Principles That Can Guide Practice". Educational Technology, 40 (1), hml 5-16.

Zimmerer, T.W., Scarborough, N.M. \& Widson, D. 2008. Essentials of Entrepreneurship and Small Business Management $\left(5^{\text {th }} \mathrm{ed}\right)$. Upper Saddle Rever, NJ: Pearson Education, Inc. 